\title{
Fundamentals of prions and their inactivation (Review)
}

\author{
AKIKAZU SAKUDO ${ }^{1}$, YASUHISA ANO ${ }^{2}$, TAKASHI ONODERA ${ }^{3}$, KAYAKO NITTA $^{4}$, \\ HIDEHARU SHINTANI $^{5}$, KAZUYOSHI IKUTA ${ }^{6}$ and YASUHARU TANAKA ${ }^{1}$
}

\begin{abstract}
${ }^{1}$ Laboratory of Biometabolic Chemistry, School of Health Sciences, Faculty of Medicine, University of the Ryukyus, 207 Uehara, Nishihara, Okinawa 903-0215; ${ }^{2}$ Central Laboratories for Frontier Technology, Kirin Holdings Co., Ltd., 1-13-5 Fukuura Kanazawa-ku, Yokohama-shi, Kanagawa 236-0004; ${ }^{3}$ Department of Molecular Immunology, School of Agricultural and Life Sciences, University of Tokyo, Bunkyo-ku, Tokyo 113-8657; ${ }^{4}$ Urasoe General Hospital, 4-16-1 Iso, Urasoe, Okinawa 901-2132; ${ }^{5}$ Faculty of Science and Engineering, Chuo University, 1-13-27 Kasuga, Bunkyo-ku,

Tokyo 112-8551; ${ }^{6}$ Department of Virology, Center for Infectious Disease Control, Research Institute for Microbial Diseases, Osaka University, Yamadaoka, Suita, Osaka 565-0871, Japan
\end{abstract}

Received September 14, 2010; Accepted December 17, 2010

DOI: 10.3892/ijmm.2011.605

\begin{abstract}
Prion is an infectious particle composed of an abnormal isoform of the prion protein $\left(\mathrm{PrPsc}^{\mathrm{S}}\right)$ and causes prion diseases such as bovine spongiform encephalopathy (BSE), Creutzfeldt-Jakob disease (CJD) and scrapie. Host cells express cellular prion protein $\left(\mathrm{PrP}^{\mathrm{C}}\right)$, which plays roles in normal functions such as anti-oxidative stress. $\mathrm{PrPSc}^{\mathrm{Sc}}$ is derived from $\mathrm{PrP}^{\mathrm{C}}$ and produced by conformational conversion. Prion is notorious as a resistant pathogen, being difficult to inactivate with conventional sterilization procedures. Therefore, to prevent prion-caused iatrogenic diseases, the use of appropriate procedures to inactivate prions is important. For examples, alcohol treatment, autoclave $\left(121^{\circ} \mathrm{C}, 20 \mathrm{~min}\right)$ and $\gamma$-ray irradiation, which are used for disinfection, antisepsis or sterilization of viruses and bacteria, are not effective against prion. This is a fundamental review of prions and methods of their inactivation.
\end{abstract}

\section{Contents}

1. Pathogens and prions

2. Methods for detecting prions

3. Iatrogenic prion disease and prion inactivation

4. Conclusions and perspectives

\section{Pathogens and prions}

Pathogens can be transmitted through food, air, drinking water, body fluids and attachment (1). There are many types,

Correspondence to: Dr Akikazu Sakudo, Laboratory of Biometabolic Chemistry, School of Health Sciences, Faculty of Medicine, University of the Ryukyus, 207 Uehara, Nishihara, Okinawa 903-0215, Japan

E-mail: sakudo@med.u-ryukyu.ac.jp

Key words: prion protein, sterilization, gas plasma including protozoa, helminths, prions, viruses, fungi, algae, mycobacteria, bacteria, viroids and bacteriophages (Fig. 1), but relatively few are directly connected to diseases. In most cases of pathogen-related diseases, the causes are not fully taken into account or sporadic, and not reported to any official agency because they are not severe or cultures are never obtained $(2,3)$. Some pathogens change their forms under some circumstances. Certain bacteria and fungi form spores under low-nutrient or dry conditions. Protozoa form oocysts and cysts dependent on their life cycle, while helminths form eggs. After an infection, viruses inject their genome into host cells. After producing viral proteins using the host cell's machinary, the virus matures. Among viruses, there are many types such as i) bacteriophages, which infect bacteria, ii) viroids, which are only RNA, devoid of proteins and infect higher plants causing crop diseases and iii) animal viruses. Animal viruses are divided into two groups; non-enveloped and enveloped (1). Besides viruses, prions (proteinaceous infectious particles) (4) have been studied in the field of virology, because they cause prion diseases, which have been classified as slow viral diseases. Prion is important, because it is the most difficult pathogen to inactivate and transmissible by eating, transfusion, and neurosurgery.

Prion diseases are neurodegenerative disorders caused by protein-based infectious particles (prions). Main component of prion is an abnormal isoform of the prion protein $\left(\mathrm{PrP}^{\mathrm{Sc}}\right)$ (5). Recently, the emergence of bovine spongiform encephalopathy (BSE) and its variant Creutzfeldt-Jakob disease (vCJD) has been highlighted. The issue has enhanced concern over food safety, safe transfusions, and safe neurosurgery. However, with the recent emergence of avian and swine influenza viruses (6), interest in BSE and vCJD has waned and information on prion diseases is still limited, especially notable in the areas of therapy and pre-mortem diagnosis.

The history of prion research is relatively long, with Cullie and Chelle reporting scrapie to be an infectious disease in 1936 (7). Although scrapie had been thought to be caused by a virus and classified as a slow viral disease, Prusiner proposed a new type of pathogen composed only of 


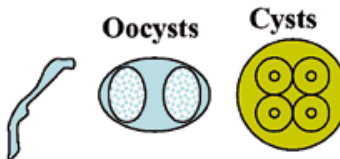

Protozoa

Cryptosporidium, Giardia, Acanthamoeba

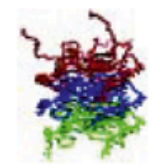

Prions

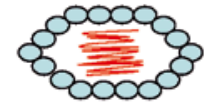

Non-enveloped viruses

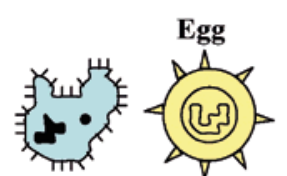

Helminth

Ascaris, Enterobius

\section{CJD, BSE, Scrapie}

\section{Adenovirus, Rotavirus,} Poliovirus, Parvovirus

\section{HIV, HBV, HSV}
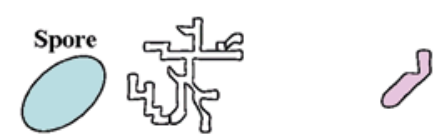

Mycobacteria

Fungi and algae

Mycobacterium

tuberculosis

Aspergillus, Penicillium, Candida

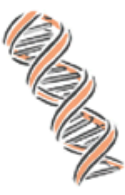

Viroid

Peach latent mosaic viroid, citrus dwarfing viroid

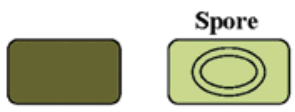

Bacteria

Gram-positive: Staphylococcus, Streptococus, Enterococcus

Gram-negative: Pseudomonas, Escherichia

Figure 1. Features of pathogens. There are various types of pathogens including protozoa, helminths, prions, viruses, fungi, algae, mycobacteria, bacteria, bacteriophages and viroids. Some pathogens change form dependent on circumstances. Some bacteria form spores under low-nutrient conditions. Fungi makes spores under dry conditions. Styles of protozoa change to oocysts and cysts with growth depending on the life cycle, while those of helminths also form eggs. Methods of detecting pathogens are closely related to the composition of pathogens. Nucleic acid-based methods are commonly used, because the genomes of all pathogens except prions are composed of nucleic acid (DNA or RNA). As prion is thought to only be composed of proteins, nucleic acid-based methods are not applicable. HIV, human immunodeficiency virus; HBV hepatitis B virus; HSV, herpes simplex virus; CJD, Creutzfeldt-Jakob disease; BSE, bovine spongiform encephalopathy. Modified from Fig. 2 in Sakudo et al (49) with permission from NOVA Science Publishers.

protein (4). Creutzfeldt-Jakob disease (CJD) and GerstmannSträussler-Scheinker disease (GSS) has been known for some time, with case reports by Creutzfeldt in 1920 (8), Jakob in 1921 (9), and Gerstmann et al in 1936 (10). The basic feature of prion disease as a transmissible spongiform encephalopathy became clear from findings for Kuru disease, which occurs in the Fore linguistic group in the Eastern Highlands of Papua New Guinea, who have a custom of eating human brain as part of mortuary rites (11). Transmission was validated by the finding that brain homogenate containing the Kuru agent caused similar symptoms to Kuru in monkeys following an intracerebral injection (11). Meanwhile, the causes of human prion diseases vary, i.e.: infection for Kuru and iatrogenic CJD (iCJD), mutation of the prion protein (PrP) gene for GSS, fatal familial insomnia (FFI) and familial CJD (fCJD), and unknown cause for sporadic CJD (sCJD) (5) (Table I). Generally, the prion diseases caused by mutation of the $\operatorname{PrP}$
Table I. Human prion diseases.

\begin{tabular}{ll}
\hline Disease & \multicolumn{1}{c}{ Cause } \\
\hline Kuru & Infection \\
iCJD & Infection \\
sCJD & Unknown \\
fCJD & Mutation of PrP gene \\
vCJD & Infection \\
GSS & Mutation of PrP gene \\
FFI & Mutation of PrP gene
\end{tabular}

CJD, Creutzfeldt-Jakob disease; iCJD, iatrogenic CJD; sCJD, sporadic CJD; fCJD, familial CJD; vCJD, variant CJD; GSS, GerstmannSträussler-Scheinker Syndrome; FFI, fatal familial insomnia; PrP, prion protein. 


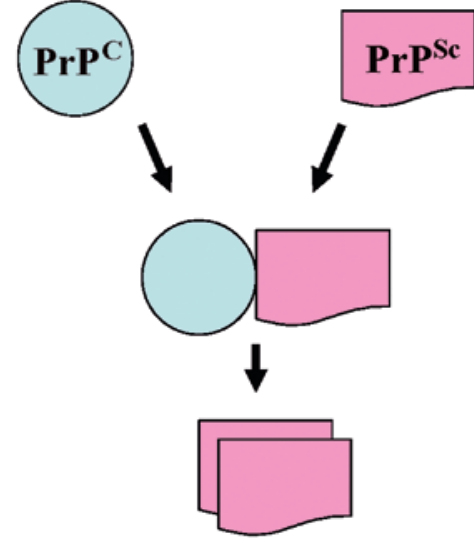

Figure 2. Conformational change of the cellular isoform of prion protein $\left(\mathrm{PrP}^{\mathrm{C}}\right)$ to an abnormal isoform of prion protein $\left(\mathrm{PrP}^{\mathrm{Sc}}\right)$. After infection, $\mathrm{PrP}^{\mathrm{C}}$ is converted into $\mathrm{PrP}^{\mathrm{Sc}}$. $\mathrm{PrP}^{\mathrm{Sc}}$ aggregates, inducing the deposition of prion protein (PrP) in the brain. The accumulation causes the death of neurons In addition, loss of $\mathrm{PrP}^{\mathrm{C}}$ may contribute to the pathogenesis, because $\mathrm{PrP}^{\mathrm{C}}$ plays a role in anti-oxidative stress, calcium homeostasis, circadian rhythms, spatial learning, and memory.

gene are relatively less infectious. These diseases have different symptoms, because the areas of the brain affected differ: for example, the cerebral cortex in CJD, the cerebellum in GSS and thalamus in FFI. Such damage is caused by neuronal cell loss, astrocytosis, and vacuolation, leading to degeneration (5). Another prion disease, $\mathrm{vCJD}$, is important in connection to BSE, which affected as many as 180,000 cattle from 1985 to 1995 in the United Kingdom (UK) (12). The total number of cattle with BSE in the UK is about 184,500 , whereas the total number in other countries is about 5,800 (13). Therefore, $>95 \%$ of BSE cases have occurred in the UK. The problem is that BSE prion is a causative agent of vCJD $(14,15)$. Meanwhile, the cause of most prion diseases (85-90\%) remains unclear. Such prion diseases are known as sporadic CJD (sCJD).

\section{Methods for detecting prions}

After an infection, cellular $\operatorname{PrP}\left(\mathrm{PrP}^{\mathrm{C}}\right)$, which is expressed in host cells, especially neurons, and has possible functions including the regulation of anti-oxidative stress, calcium and copper homeostasis, circadian rhythms, spatial learning, memory, signalling, and synapse formation $(16,17)$, changes into $\mathrm{PrP}^{\mathrm{Sc}}$ (Fig. 2). $\mathrm{PrP}^{\mathrm{Sc}}$ accumulates in the brain and forms PrP deposits, which are protease-resistant (Table II). The accumulation causes neuronal cell loss, astrocytosis, and vacuolation, leading to spongiform and eventually death (18). Prion diseases, unlike other amyloid diseases, are transmissible. Generally, transmission is more difficult between different species than between identical species, a phenomenon known as the 'species barrier' (19). However, BSE can be transmitted to humans, resulting in vCJD (14), whereas epidemiological data suggest that scrapie cannot directly infect humans. Therefore, the study of BSE is important in terms of food hygiene (20). In Japan, all cows over 21 months old are checked for BSE (21). The method is as follows (Fig. 3): a homogenate is prepared from the brain obex and treated with proteinase $\mathrm{K}(\mathrm{PK})$. The treated sample is applied to a microtiter plate for
Table II. Characteristics of $\operatorname{PrP}^{\mathrm{C}}$ and $\mathrm{PrP}^{\mathrm{Sc}}$.

\begin{tabular}{lll}
\hline & \multicolumn{1}{c}{$\operatorname{PrP}^{\mathrm{C}}$} & \multicolumn{1}{c}{$\operatorname{PrP}^{\mathrm{Sc}}$} \\
\hline $\begin{array}{l}\text { Resistance to protease } \\
\text { Distribution in cell }\end{array}$ & Low & High \\
GPI anchor & Present & Intracell \\
Release from cell & Positive & Present \\
surface by PIPLC & & Negative \\
Half life & $3-6 \mathrm{~h}$ & \\
Solublity & High & $>24 \mathrm{~h}$ \\
Conformation & $42 \% \alpha$-helix, & $30 \% \alpha$-helix, \\
& $3 \% \beta$-sheet & $43 \% \beta$-sheet \\
Infectivity & Negative & Positive \\
\hline
\end{tabular}

$\mathrm{PrP}^{\mathrm{C}}$, cellular isoform of prion protein; $\mathrm{PrP}^{\mathrm{Sc}}$, abnormal isoform of prion protein; GPI, glycosylphosphatidyl inositol; PIPLC, phosphatidyl-inositol specific phospholipase C.

absorption then detected with anti-PrP antibody. If the result is positive, the above-mentioned enzyme-linked immunosorbent assay (ELISA) is performed repeatedly. If a positive result is obtained again, Western blotting and immunohistochemistry (IHC) are performed (Fig. 4). The Western blotting uses a membrane to absorb PK-treated proteins separated by sodium dodecyl sulfate (SDS)-polyacrylamide gel electrophoresis (PAGE). After the absorption, PK-resistant PrP (PrPres) in the membrane-bound proteins is detected with anti-PrP antibody. Importantly, Western blotting provides information on not only prion infections but also the mobility of peptides, which is influenced by the host genotype and prion strains $(22,23)$. As shown in Fig. 4B, the IHC is based on representative pathological features of prion diseases including neuronal cell loss, vacuolation, astrocytosis and amyloid plaques. In the IHC analysis of brain sections, the accumulation of PrP amyloid plaques, neuronal cell loss (or vacuolation) and astrocytosis are examined by light microscopy. Although vacuolation is also used as an index of prion infection, various combinations of prion strains with host species result in the accumulation of PrP without vacuolation in brain sections $(24,25)$. Recently, the protein misfolding cyclic amplification (PMCA) method has been developed (26), which enables in vitro amplification of $\mathrm{PrP}^{\mathrm{res}}$ from a small quantity of $\mathrm{PrP}^{\mathrm{Sc}}$ as seed by sequential cycles of incubation and sonication. Interestingly, levels of PrPres amplified by this method correlated with the prion infectivity titer (27). Furthermore, PMCA could detect prions in blood (28). In addition, it could be used to diagnose not only terminally diseased hamsters but also prion-infected pre-symptomatic hamsters (29). This method has the highest sensitivity of any method for detecting $\mathrm{PrP}^{\text {res }}$ reported so far. To date, its application to sheep (28), goat (30), cattle (30), sCJD (30), vCJD (31), CWD (32) and hamster scrapie (26) and mouse scrapie (33) has been reported. Recently, PMCA has been modified, leading to recombinant PrP-PMCA (rPrPPMCA) (34) and its combination with the quaking-induced conversion (QUIC) reaction $(34,35)$. In addition, information obtained from PMCA will contribute to understanding the 


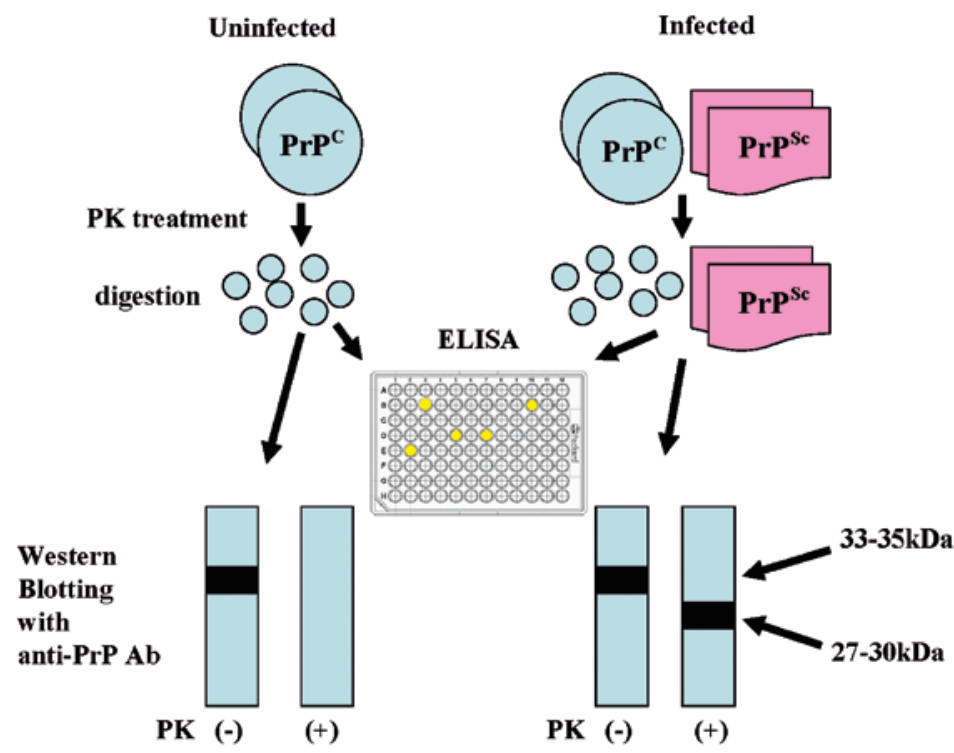

Figure 3. Diagnostic methods for prion infections. For the diagnosis of prion diseases, brain tissue is used. Therefore, the diagnosis is post-mortem. Most methods of diagnosing prion diseses are based on the characteristics of $\mathrm{PrP}^{\mathrm{Sc}}$, which is resistant to proteinase $\mathrm{K}(\mathrm{PK})$. $\mathrm{PK}$ completely degrades $\mathrm{PrP}^{\mathrm{C}}$ but only partially digests $\operatorname{PrP}^{\mathrm{Sc}}$, because $\mathrm{PrP}^{\mathrm{Sc}}$ makes aggregates and those cores remain. After the treatment, Western blotting and enzyme-linked immunosorbent assay (ELISA) with anti-PrP antibody detect PK-resistant PrP, when $\mathrm{PrP}^{\mathrm{sc}}$ is included in the sample. As the N-terminal region of $\mathrm{PrP}^{\mathrm{sc}}$ is digested with PK(+), PK-resistant PrP (27-30 kDa) shows a shift to a lower molecular weight compared to untreated PrP(-) (33-35 kDa) in Western blotting.

mechanism of conformational change of PrP. So far, several factors such as RNA and metals have been found to be involved in the conformational change using PMCA $(36,37)$. Furthermore, in vivo analyses of the use of such factors may provide clues to the treatment of prion diseases.

\section{Iatrogenic prion disease and prion inactivation}

Although 4 cases of iCJD caused by neurosurgery have been reported, all are from the 1980s or earlier. Therefore, a causal relationship remains to be determined (38). However, difficulty in the inactivation of prions requires appropriate treatment of the surgical instruments used for craniotomy, spinal surgery, ophthalmologic surgery, etc. The most important difference between prion and other pathogens is that prion has no nucleic acid (5). Therefore, it cannot be inactivated by conventional sterilization procedures such as autoclaving $\left(121^{\circ} \mathrm{C}, 20 \mathrm{~min}\right)$, exposure to UV and $\gamma$-ray irradiation (5). Although alcohol treatments such as $70 \%$ ethanol are effective for bacteria and enveloped viruses, they have no effect on prions. To inactivate prions, use of an autoclave under severe condition $\left(134^{\circ} \mathrm{C}\right.$, $18 \mathrm{~min}), \mathrm{NaOH}\left(1 \mathrm{~N}, 20^{\circ} \mathrm{C}, 1 \mathrm{~h}\right), \mathrm{SDS}\left(30 \%, 100^{\circ} \mathrm{C}, 10 \mathrm{~min}\right)$, and $\mathrm{NaOCl}\left(20000 \mathrm{ppm}, 20^{\circ} \mathrm{C}, 1 \mathrm{~min}\right)$ is recommended (Table III). As a practical method for prion inactivation, the following procedures are recommended (38). i) Washing with appropriate detergents + SDS treatment (3\%, 3-5 min), ii) treatment with alkaline detergents $\left(80-93^{\circ} \mathrm{C}, 3-10 \mathrm{~min}\right)+$ autoclaving $\left(134^{\circ} \mathrm{C}, 8-10 \mathrm{~min}\right)$, iii) washing with appropriate detergents + autoclaving $\left(134^{\circ} \mathrm{C}, 18 \mathrm{~min}\right)$ and iv) washing with alkaline detergents (at a concentration and temperature according to instructions) + vaporized hydrogen peroxide gas plasma sterilization. The most important point is that a dried prion-infected apparatus is difficult to be sterilized. Therefore, after use of the apparatus, prompt washing is essential (38).
A

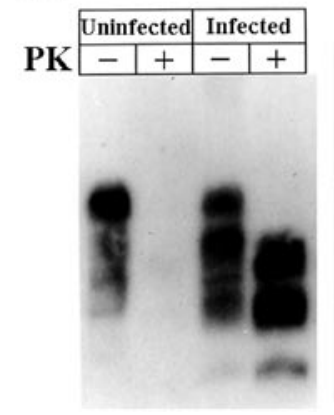

B

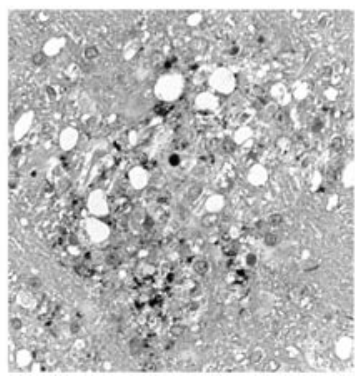

Figure 4. Western blotting and immunohistochemistry (IHC). (A) PrP from brain membranous fractions of uninfected mice (uninfected) and terminally diseased mice intracerebrally inoculated with Obihiro- 1 prions (infected) was detected by Western blotting with anti-PrP antibody, 6H4 and horseradish peroxidase (HRP)-conjugated anti-mouse IgG. Each fraction was treated (+) or not (-) with PK. Modified from Fig. 1 in Inoue et al (50) with permission from the National Institute of Infectious Diseases. (B) Immunohistochemistry of the brains of terminally prion-diseased mice infected with Obihiro-1 prions. PrP was detected by an anti-PrP antibody, 6H4. Vacuolation and PrP deposits were seen. Courtesy of Dr Yuji Inoue (Department of Virology, Center for Infectious Disease Control, Research Institute for Microbial Diseases, Osaka University, Japan).

Then, autoclaving at $134^{\circ} \mathrm{C}$ and vaporized hydrogen peroxide gas plasma sterilization, etc. should be performed for prion inactivation.

Finally, we focus on gas plasma sterilization. Although not as well known as major sterilization procedures like autoclaving, there are various reports on prion inactivation using this method (39). Gas plasma is the fourth state of matter after solid, liquid and gas (40). Gas plasma is generated by removing electrons and producing a highly excited mixture of charged 
Table III. Effective treatment on inactivation of prion.

Treatment

Refs.

$\mathrm{NaOCl}\left(20000 \mathrm{ppm}, 20^{\circ} \mathrm{C}, 1 \mathrm{~h}\right)$

$\mathrm{NaOH}\left(1 \mathrm{~N}, 20^{\circ} \mathrm{C}, 1 \mathrm{~h}\right)$

Autoclave under soaked condition in water $\left(134^{\circ} \mathrm{C}, 18 \mathrm{~min}\right)$

Alkaline detergent $\left(1.6 \%, 43^{\circ} \mathrm{C}, 15 \mathrm{~min}\right)$

Phenolic disinfectant $\left(5 \%, 20^{\circ} \mathrm{C}, 30 \mathrm{~min}\right)$

$3 \% \operatorname{SDS}, 100^{\circ} \mathrm{C}, 10 \mathrm{~min}$

$7 \mathrm{M}$ guanidine hydrochloride (room temperature, $2 \mathrm{~h}$ )

$3 \mathrm{M}$ guanidine thiocyanate (room temperature, $2 \mathrm{~h}$ )

$3 \mathrm{M}$ trichloroacetic acid (room temperature, $2 \mathrm{~h}$ )

$60 \%$ formic acid (room temperature, $2 \mathrm{~h}$ )

$50 \%$ phenol (room temperature, $2 \mathrm{~h}$ )

Enzymatic detergent $\left(0.8 \%, 43^{\circ} \mathrm{C}, 5 \mathrm{~min}\right)+$ hydrogen peroxide gas plasma sterilization $\left(1.5 \mathrm{mg} / 1,25^{\circ} \mathrm{C}, 3 \mathrm{~h}\right)$

Vaporized hydrogen peroxide $\left(2 \mathrm{mg} / 1,30^{\circ} \mathrm{C}, 3\right.$ cycles $)$

*Autoclaving with no soaking in water is insufficient for prion inactivation (dry conditions cause difficulty in inactivation) $(39,52)$ *Enzymatic detergent $\left(0.8 \%, 43^{\circ} \mathrm{C}, 5 \mathrm{~min}\right)+$ autoclave $\left(121^{\circ} \mathrm{C}, 20 \mathrm{~min}\right)$, only enzymatic detergent $\left(0.8 \%, 43^{\circ} \mathrm{C}, 5 \mathrm{~min}\right)$, only peroxyacetic acid $(0.25 \%$, $\left.55^{\circ} \mathrm{C}, 12 \mathrm{~min}\right)$, only vaporized hydrogen peroxide gas $\left(1.5 \mathrm{mg} / 1,25^{\circ} \mathrm{C}, 3 \mathrm{~h}\right)$, or enzymatic detergent $\left(0.8 \%, 43^{\circ} \mathrm{C}, 5\right.$ min $)+$ vaporized hydrogen peroxide gas $\left(1.5 \mathrm{mg} / 1,25^{\circ} \mathrm{C}, 3 \mathrm{~h}\right)$ are insufficient for prion inactivation. SDS, sodium dodecyl sulfate.

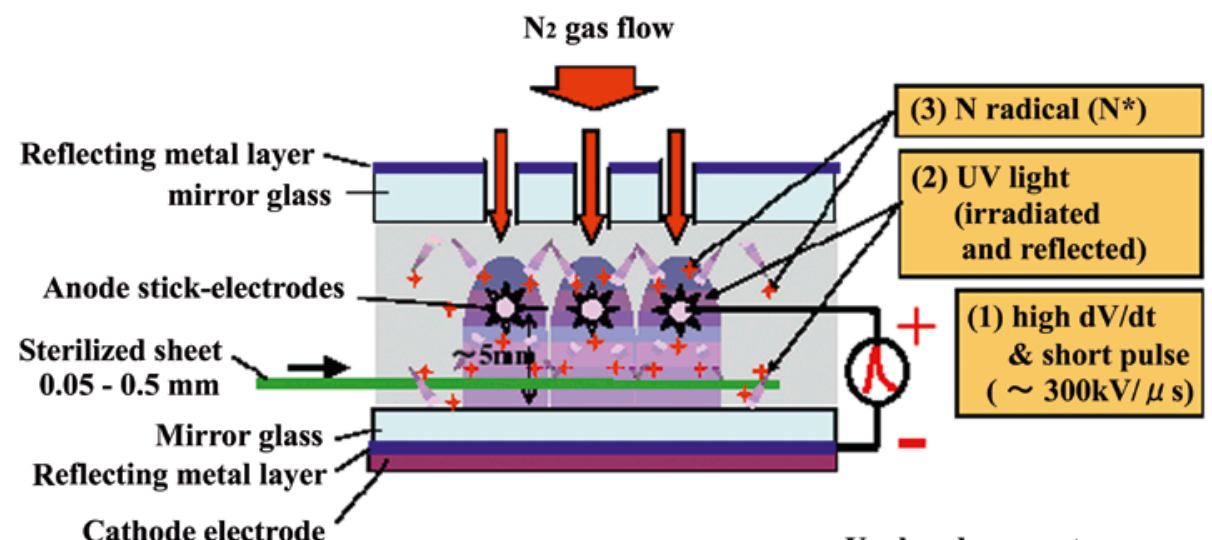

Cathode electrode

Unclosed apparatus

Figure 5. Constitution of $\mathrm{N}_{2}$ gas plasma sterilization apparatus. Atmosphere in the apparatus with an $\mathrm{N}_{2}$ gas flow. Under the conditions, high dV/dt and short pulses were applied, resulting in the generation of gas plasma. The possible sterilization mechanisms are as follows. (1) high dV/dt and short pulses, (2) UV exposure, (3) N radical. Cited from Fig. 1(a) in Shintani et al, (40) with permission from Society for Antibacterial and Antifungal Agents, Japan. UV, ultraviolet.

nuclei and free electrons in a chamber containing active gasses like vaporized hydrogen peroxide or inactive gasses like nitrogen (40). The process is achieved by the supply of sufficient energy, in the form of heat or an electromagnetic field, to gas. Currently, there is only one commercial gas plasma steril-

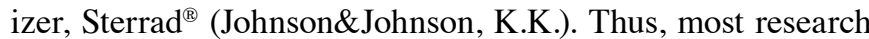
on gas plasma sterilization is performed using this machine. Studies using gas plasma instruments including developing instruments beside those of prion (39) reported inactivation of human immunodeficiency virus (HIV) (41) hepatitis A virus (41), respiratory syncytial virus (RSV) (41), vaccinia virus (41), herpes simplex virus (HSV) (41), poliovirus (41), duck hepatitis B virus (42), bacterial spores (43-45) and endotoxin
(40). However, the sterilization mechanisms are not simple. In the case of Sterrad ${ }^{\circledR}$, the mechanism of action seems to be the effect of vaporized hydrogen peroxide, not that of gas plasma. In this case, gas plasma appears to contribute to the elimination of remaining toxic vaporized hydrogen peroxide after the reaction. In contrast, nitrogen and noble gasses (Argon and Helium) do not themselves have a biocidal effect, but their gas plasmas are effective for inactivation of pathogens. Therefore, gas plasmas of nitrogen and noble gasses have complicated mechanisms of radical production, UV exposure and high dV/ dt and short pulse (Fig. 5) (40). Such an approach using inactive gasses is promising for the sterilization of fragile medical devices, especially endoscopes (46). 


\section{Conclusions and perspectives}

Prion has the unique feature of being devoid of nucleic acid. Therefore, its inactivation requires different procedures from those applied to other pathogens. In addition, prion diseases are zoonotic infectious diseases (5). Notably, the BSE prion causes vCJD in humans, and can be transmitted via blood (47). Current diagnostic methods for prion diseases are post-mortem, though recent research has achieved drastic improvements and enabled a highly sensitive diagnosis. Notably, PMCA raises the possibility of a pre-mortem diagnosis using blood samples not only from terminally ill individuals but also from preclinical onset (29). Gas plasma sterilization is a promising method potentially effective against all microorganisms including prions. This approach would offer profound advantages over conventional methods. By introducing appropriate gases into the system, certain gases critical for sterilizing each microorganism may be elucidated.

Finally, the authors note that the information is based on scientific publications at the time of preparation. Therefore, the authors and publisher take no responsibility for any consequences of the application of any of the information in this review by any reader. Recently, guidelines for 'Disinfection and sterilization in healthcare facilities, 2008' by the Centers for Disease Control and Prevention (CDC) (48) and guidelines for control of prion diseases, 2008 by the Research Committee on Prion Disease and Slow Virus Infection, The Ministry of Health, Labour and Welfare of Japan (38) have been published. For clinical issues relating to disinfection and sterilization, these guidelines are appropriate for consultation.

\section{Acknowledgements}

This study was supported by grants-in-aid for scientific research and grants-in-aid for scientific research on Innovative Areas (research in a proposed area) from the Ministry of Education, Sciences, Sports and Technology (MEXT). This work was also supported by Grants-in-aid from the Research Committee of Prion Disease and Slow Virus Infection, the Ministry of Health, Labour and Welfare of Japan.

\section{References}

1. Knipe DM, Howley PM, Griffin DE, Lamb RA and Martin MA Fields Virology. 5th edition. Lippincott Williams \& Wilkins, Pennsylvania, 2006.

2. Gorski L and Csordas A: Molecular detection: principles and methods. In: Molecular Detection of Foodborne Pathogens. Liu D (ed). CRC Press, New York, pp1-20, 2009.

3. WHO: Food safety and food borne illness. https//www.who. $\mathrm{int} / \mathrm{mediacentre/factsheets/fs237/en/index.html} \mathrm{(accessed}$ September 6, 2010).

4. Prusiner SB: Novel proteinaceous infectious particles cause scrapie. Science 216: 136-144, 1982.

5. Prusiner SB: Prions. Proc Natl Acad Sci USA 95: 13363-13383, 1998.

6. Sym D, Patel PN and El-Chaar GM: Seasonal, avian, and novel H1N1 influenza: prevention and treatment modalities. Ann Pharmacother 43: 2001-2011, 2009.

7. Cuille J and Chelle PL: Pathologie animal - la maladie dite tremblante du mouton est-elle inoculable? C R Acad Sci 203 $1552-1554,1936$

8. Creutzfeldt HG: Über eine eigenartige herdförmige Erkrankung des Zentralnervensystems. Vorläufige Mitteilung. Zeitschrift für die gesamte Neurologie und Psychiatrie 57: 1-18, 1920.
9. Jakob A: Über eigenartige Erkrankungen desZentralnervensystems mit bemerkenswerten anatomischen Befunde (spastische Pseudosklerose-Encephalomyelopathie mit disseminierten Degenerationsherden). Vorläufige Mitteilung. Deutsche Zeitschrift für Nervenheilkunde 70: 132-146, 1921.

10. Gerstmann J, Sträussler E and Scheinker I: Über eine eigenartige hereditär-familiäre Erkrankung des Zentralnervensystems. Zugleich ein Beitrag zur Frage des vorzeitigen lokalen Alterns. Zeitschrift für die gesamte Neurologie und Psychiatrie 154: 736-762, 1936.

11. Gajdsek DC and Gibbs CJ: Transmission of two subacute spongiform encephalopathies of man (kuru and CreutzfeldtJakob disease) to New World monkeys. Nature 230: 588-591, 1971.

12. Anderson RM, Donnelly CA, Ferguson NM, et al: Transmission dynamics and epidemiology of BSE in British cattle. Nature 382: 779-788, 1996.

13. OIE: Number of reported cases of bovine spongiform encephalopathy (BSE) in farmed cattle worldwide. http://www.oie.int/ eng/info/en_esbmonde.htm (accessed September 6, 2010).

14. Hill AF, Desbruslais M, Joiner S, et al: The same prion strain causes vCJD and BSE. Nature 389: 448-450, 1997.

15. Bruce ME, Will RG, Ironside JW, et al: Transmissions to mice indicate that 'new variant' CJD is caused by the BSE agent. Nature 389: 498-501, 1997.

16. Sakudo A and Ikuta K: Fundamentals of prion diseases and their involvement in the loss of function of cellular prion protein. Protein Pept Lett 16: 217-229, 2009.

17. Sakudo A, Onodera T, Suganuma Y, Kobayashi T, Saeki K and Ikuta K: Recent advances in clarifying prion protein functions using knockout mice and derived cell lines. Mini Rev Med Chem 6: 589-601, 2006.

18. Sakudo A and Ikuta K: Prion protein functions and dysfunction in prion diseases. Curr Med Chem 16: 380-389, 2009.

19. WHO: Prion diseases. http://www.who.int/zoonoses/diseases/ prion_diseases/en/ (accessed September 6, 2010).

20. Onodera T and Kim CK: BSE situation and establishment of Food Safety Commission in Japan. J Vet Sci 7: 1-11, 2006.

21. Food Safety Commission: BSE\&vCJD. http://www.fsc.go.jp/ english/topics/bseandvcjd.html (accessed September 6, 2010).

22. Pan T, Colucci M, Wong BS, et al: Novel differences between two human prion strains revealed by two-dimensional gel electrophoresis. J Biol Chem 276: 37284-37288, 2001.

23. Thuring CM, Erkens JH, Jacobs JG, et al: Discrimination between scrapie and bovine spongiform encephalopathy in sheep by molecular size, immunoreactivity, and glycoprofile of prion protein. J Clin Microbiol 42: 972-980, 2004.

24. Iwata N, Sato Y, Higuchi Y, et al: Distribution of $\operatorname{PrP}(\mathrm{Sc})$ in cattle with bovine spongiform encephalopathy slaughtered at abattoirs in Japan. Jpn J Inf Dis 59: 100-107, 2006.

25. Orge L, Galo A, Machado C, et al: Identification of putative atypical scrapie in sheep in Portugal. J Gen Virol 85: 3487-3491, 2004.

26. Saborio GP, Permanne B and Soto C: Sensitive detection of pathological prion protein by cyclic amplification of protein misfolding. Nature 411: 810-813, 2001.

27. Castilla J, Saa P, Hetz C and Soto C: In vitro generation of infectious scrapie prions. Cell 121: 195-206, 2005.

28. Thorne L and Terry LA: In vitro amplification of PrPSc derived from the brain and blood of sheep infected with scrapie. J Gen Virol 89: 3177-3184, 2008.

29. Saa P, Castilla J and Soto C: Presymptomatic detection of prions in blood. Science 313: 92-94, 2006.

30. Soto C, Anderes L, Suardi S, et al: Pre-symptomatic detection of prions by cyclic amplification of protein misfolding. FEBS Lett 579: 638-642, 2005.

31. Jones M, Peden AH, Prowse CV, et al: In vitro amplification and detection of variant Creutzfeldt-Jakob disease PrPSc. J Pathol 213: 21-26, 2007

32. Kurt TD, Perrott MR, Wilusz CJ, et al: Efficient in vitro amplification of chronic wasting disease PrPRES. J Virol 81: 9605-9608, 2007.

33. Murayama Y, Yoshioka M, Yokoyama T, et al: Efficient in vitro amplification of a mouse-adapted scrapie prion protein. Neurosci Lett 413: 270-273, 2007.

34. Atarashi R, Wilham JM, Christensen L, et al: Simplified ultrasensitive prion detection by recombinant PrP conversion with shaking. Nat Methods 5: 211-212, 2008.

35. Atarashi R: Recent advances in cell-free PrPSc amplification technique. Protein Pept Lett 16: 256-259, 2009. 
36. Kim NH, Choi JK, Jeong BH, et al: Effect of transition metals $(\mathrm{Mn}, \mathrm{Cu}, \mathrm{Fe})$ and deoxycholic acid (DA) on the conversion of PrPC to PrPres. FASEB J 19: 783-785, 2005.

37. Deleault NR, Lucassen RW and Supattapone S: RNA molecules stimulate prion protein conversion. Nature 425: 717-720, 2003.

38. Mizusawa $\mathrm{H}$ and Kuroiwa $\mathrm{Y}$ : Guideline for infection control of prion diseases 2008. The Research Committee on Prion Disease and Slow Virus Infection, Research on Measures for Intractable Diseases Health and Labour Sciences Research Grants, The Ministry of Health, Labour and Welfare, Japan. http://prion. umin.jp/guideline/index.html (accessed September 6, 2010).

39. Fichet G, Comoy E, Duval C, et al: Novel methods for disinfection of prion-contaminated medical devices. Lancet 364 : 521-526, 2004

40. Shintani H, Shimizu N, Imanishi Y, et al: Inactivation of microorganisms and endotoxins by low temperature nitrogen gas plasma exposure. Biocontrol Sci 12: 131-143, 2007.

41. Roberts $C$ and Antonoplos P: Inactivation of human immunodeficiency virus type 1 , hepatitis A virus, respiratory syncytial virus, vaccinia virus, herpes simplex virus type 1 , and poliovirus type 2 by hydrogen peroxide gas plasma sterilization. Am J Infect Control 26: 94-101, 1998.

42. Vickery K, Deva AK, Zou J, Kumaradeva P, Bissett L and Cossart YE: Inactivation of duck hepatitis B virus by a hydrogen peroxide gas plasma sterilization system: laboratory and 'in use' testing. J Hosp Infect 41: 317-322, 1999.

43. Roth S, Feichtinger J and Hertel C: Characterization of Bacillus subtilis spore inactivation in low-pressure, low-temperature gas plasma sterilization processes. J Appl Microbiol 108: 521-531, 2010.

44. Hong YF, Kang JG, Lee HY, Uhm HS, Moon E and Park YH: Sterilization effect of atmospheric plasma on Escherichia coli and Bacillus subtilis endospores. Lett Appl Microbiol 48: 33-37, 2009.
45. Okpara-Hofmann J, Knoll M, Durr M, Schmitt B and BorneffLipp M: Comparison of low-temperature hydrogen peroxide gas plasma sterilization for endoscopes using various Sterrad models. J Hosp Infect 59: 280-285, 2005.

46. McDonnell GE: Antisepsis, disinfection and sterilization: types, action, and resistance. ASM Press, Washington DC, 2007.

47. Houston F, Foster JD, Chong A, Hunter N and Bostock CJ: Transmission of BSE by blood transfusion in sheep. Lancet 356 : 999-1000, 2000

48. Rutala WA and Weber DJ: HICPAC, guideline for disinfection and sterilization in healthcare facilities, 2008. http://www.cdc. gov/ncidod/dhqp/pdf/guidelines/Disinfection_Nov_2008.pdf (accessed September 6, 2010).

49. Sakudo A, Onodera T and Tanaka Y: Inactivation of viruses. In: Sterilization Mechanisms, Biological and Medical Applications. Sakudo A and Shintani H (eds). NOVA Science Publishers Inc., New York (In press).

50. Inoue Y, Yamakawa Y, Sakudo A, et al: Infection routeindependent accumulation of splenic abnormal prion protein. Jpn J Infect Dis 58: 78-82, 2005.

51. Tateishi J, Tashima T and Kitamoto T: Practical methods for chemical inactivation of Creutzfeldt-Jakob disease pathogen. Microbiol Immunol 35: 163-166, 1991.

52. Vadrot C and Darbord JC: Quantitative evaluation of prion inactivation comparing steam sterilization and chemical sterilants: proposed method for test standardization. J Hosp Infect 64: $143-148,2006$. 